\title{
SARS-COV-2 AND ITS POSSIBLE ASSOCIATION WITH THE ONSET OF AUTOIMMUNE DISEASES. A CASE REPORT OF SYSTEMIC LUPUS ERYTHEMATOSUS IN A PATIENT WITH COVID-19
}

Aline Rizzo Borges ${ }^{1, \star}$, Alexandre Shigemi Vicente Hidaka², Ana Carolina Emy Vicente Hidaka², Viviane Cristina Uliana Peterle ${ }^{1,3}$, Cleandro Pires de Albuquerque ${ }^{4}$, Licia Maria Henrique da Mota ${ }^{4}$ Rebeca Naoum Lorga ${ }^{1}$, Heloisa Lima Heller ${ }^{1}$, Luís Otávio Amarante Franco ${ }^{1}$, João Pedro de Oliveira Aucelioํ․, Marcos Igor Albanaz Vargas ${ }^{1}$, Ciro Moisés Oliveira Vieira dos Santos ${ }^{1}$, Beatriz Toledo Mendes ${ }^{1}$, Beatriz Carneiro Passos ${ }^{1}$, Gustavo Araujo do Nascimento Santos ${ }^{1}$, Maurício Silva de Jesus ${ }^{1}$, Beatriz Pires Paes1, Maria Luiza Pimentel de Oliveira ${ }^{1}$, Paulo Ricardo Guimarães Rocha Storni ${ }^{6}$, Natália Vargas do Nascimento ${ }^{5}$, Ana Beatriz Caetano Vieira ${ }^{5}$, Gabriela Furlan Ribeiro Barbosa Netto ${ }^{5}$, Maria Teresa Aires Cabral Dias ${ }^{5}$, Ana Paula Monteiro Gomides ${ }^{1}$

1.Centro Universitário de Brasília, Brasília (DF), Brazil. 2.Hidaka Clínica de Reumatologia, Brasília (DF), Brazil. 3.Escola Superior de Ciências da Saúde, Brasília (DF), Brazil. 4.Universidade de Brasília, Brasília (DF), Brazil. 5.Universidade Católica de Brasília, Brasília (DF), Brazil. 6.Centro Universitário Euro-Americano, Brasília (DF), Brazil.

*Corresponding author: aline_rizzo_borges@hotmail.com

\section{BACKGROUND}

Systemic lupus erythematosus (SLE) is an autoimmune multisystemic inflammatory disease. Clinical manifestations can transpire slowly and progressively or rapidly. Coronavirus disease 2019 (COVID-19) is an infectious disease caused by a newly discovered coronavirus. One of the responses to severe acute respiratory syndrome coronavirus 2 (SARS-CoV-2) infection is a "cytokine storm". This excessive immune response can trigger activation of SLE genes in predisposed patients. Molecular mimicry of the virus and human protein is an additional and possible theory to explain autoimmune reactivity. The objective of presenting this case report is to discuss the possible association between concomitant infection of SARS-CoV-2 and the presentation of SLE.

\section{CASE REPORT}

Previously healthy 42 -year-old woman, presented with fever $\left(38^{\circ} \mathrm{C}\right)$, symmetrical pain and edema of hands, feet, knees and ankles, which appeared in July 2020. After one week, she evolved with ventilatory dependent chest pain and tachypnea. 30 days after the emergence of manifestations, the patient was submitted to a rheumatological evaluation. Clinical examination revealed polyarthritis and altered pulmonary auscultation. Complementary exams were carried out and revealed: Hb: 9.4; Htc: 27.9; Gl: 4800; L: 1824; PI: 524,000; VHS: 120 mm/h; PCR: 112.6; FAN: 1/2560 (homogeneous nuclear dense speckled pattern); anti-DNA: 1/160; anti-RNP: 220; anti-Ro, La eSM: negative; C3: 86; C4: 7.1; direct COOMBS: ++; proteinuria 24 h: 522 mg/24 h; EAS: protein +; serology testing for COVID-19: IgM negative e IgG positive ( $84.5 \mathrm{mg} / \mathrm{dL}$ ). Echocardiography and tomography were also performed and showed a mild pericardial effusion and subpleural band-like infiltration, with ground glass attenuation at the right posterior basal segment (suggestive of viral pneumonia). With these results, SLE and previous SARS-CoV-2 were diagnosed. Therefore, prednisone $20 \mathrm{mg}$, hydroxychloroquine $400 \mathrm{mg}$ and symptomatic were prescribed, resulting in complete improvement of the symptoms in 30 days.

\section{CONCLUSION}

Coronavirus disease 2019 can cause an exacerbated immune response in the body from the release of cytokines, which can trigger SLE and other autoimmune diseases in predisposed patients. In this case, one patient previously had SARS-CoV-2 with positive IgG, which was possibly a trigger for the onset of SLE manifestations. Thus, the importance of a correct diagnosis and the rapid initiation of treatment to reduce morbidity and mortality are highlighted. 